\section{Tropical Journal of Pathology and Microbiology}

2020 Volume 6 Number 5 May-June

\title{
Correlation of ER, PR, Her2neu and Ki67 with other Prognostic factors in Breast Carcinoma
}

\author{
Reddy P. ${ }^{1}$, Mithraa DS. ${ }^{2 *}$ \\ DOI: https://doi.org/10.17511/jopm.2020.i05.01
}

\footnotetext{
${ }^{1}$ Purushotham Reddy, Professor and HOD, Department of Pathology, Karnataka Institute of Medical Sciences, Hubballi, Karnataka, India.

2* Mithraa Devi S, Consultant Pathologist, Hitech Diagnostic Centre, Chennai, Tamil Nadu, India.
}

Background: In females, breast carcinoma is the most common malignancy accounting for $23 \%$ of all malignant tumours. Various predictive and prognostic factors affect tumour progression. In addition to estrogen receptors (ER), progesterone receptors (PR) and human epidermal growth factor receptor (Her2neu), recently Ki67, a proliferative marker has been recognized as an important predictive and prognostic marker in many studies. The aim of the study was to find the correlation of ER, PR, Her2neu and Ki67 tumour markers with menopausal status, tumour size, histopathological grade, mitotic index, lymphovascular invasion and lymph node metastasis. Methods: The present study was conducted on 50 cases of breast carcinomas. The histopathological grading of the breast carcinoma was done according to the Nottingham modification of the Bloom Richardson grading system. All the cases underwent immunohistochemistry for ER, PR, Her2neu and Ki67 expression. Correlation of ER, PR, Her2neu and Ki67 with various prognostic factors was done. Results: The expression of $\mathrm{ER}$ and $\mathrm{PR}$ decreased as the grade of the tumour increased. Ki67 proliferative index increased as the grade of the tumour increased. Ki67 proliferative index also increased as the mitotic count increased. None of these markers showed a correlation with other prognostic factors. Conclusion: The present study concludes that ER, PR reveals inverse relationship and Ki67 showed a direct relationship with the grade of the tumour.

Keywords: Breast Carcinoma, Estrogen receptors, Progesterone receptors, Human epidermal growth factor receptor, Ki67

Corresponding Author

Mithraa Devi S, Consultant Pathologist, Hitech Diagnostic Centre, Chennai, Tamil Nadu, India. Email: mithraasekar@gmail.com
How to Cite this Article

To Browse

Reddy P, Mithraa SD. Correlation of ER, PR, Her2neu and $\mathrm{Ki} 67$ with other Prognostic factors in Breast Carcinoma. Trop J Pathol Microbiol. 2020;6(5):349361.

Available From

https://pathology.medresearch.in/index.php/jopm/ar ticle/view/459

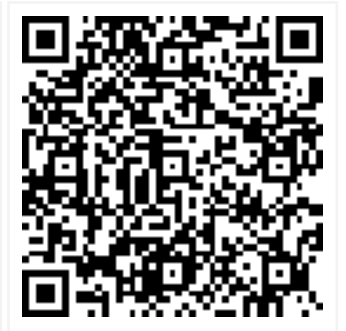

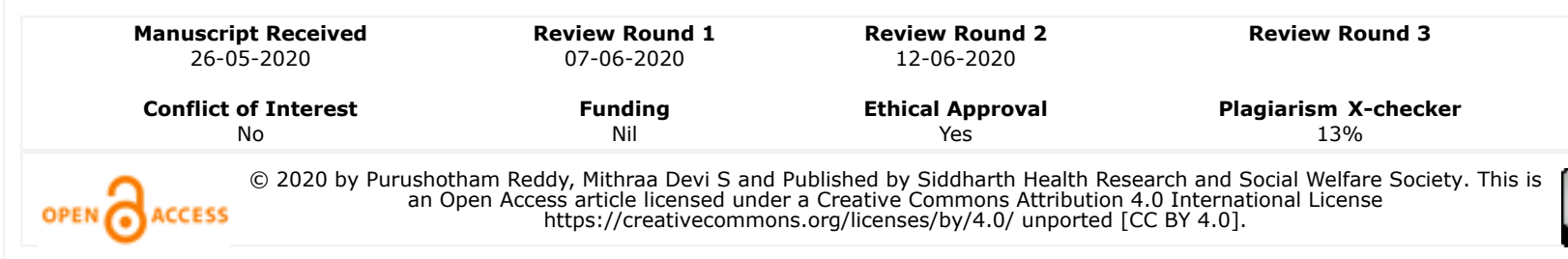




\section{Introduction}

Breast carcinoma (BC) is the most common malignancy and also causes the highest number of cancer-related deaths among women. In 2018 about 20,88,849 new cases were reported and $6,26,679$ women died of breast carcinoma in the world [1].

According to the global cancer observatory data, breast cancer has been ranked as the most common cancer among Indian females [1,2]. In India, in 2018 about 1,62,468 new cases and 87,090 deaths were reported for breast cancer according to GLOBOCAN data. With an incidence of $14 \%$ cases, it has become the most common cancer among females and even overall [2].

The patient's outcome can be anticipated through prognostic factors. These prognostic factors can be used to estimate the response to therapy and some are useful as predictive factors. Factors that are both prognostic and predictive include estrogen receptor (ER) and progesterone receptor (PR) status and human epidermal growth factor receptor (Her2neu).

Recently Ki67, a proliferative marker has been recognised as an important predictive and prognostic marker in many studies [3]. Independent prognostic factors include the type of tumour, number of involved lymph nodes, size of the tumour, tumour grade and the patient's age[4].

\section{Aim of the Study}

- To evaluate the expression of ER, PR, Her2neu and $\mathrm{Ki} 67$ proliferative index in single institute patients.

- To compare the expression of these factors with other prognostic parameters such as menopausal status, size of the tumour, grade, histological type, mitotic index, lymphovascular invasion and nodal metastasis.

\section{Materials and Methods}

Setting- The present study was done in a tertiary care hospital, in the Department of Pathology, Karnataka Institute of Medical Sciences, Hubballi, Karnataka, India

Duration- The present study was done in the Department of Pathology, Karnataka Institute of Medical Sciences, Hubballi, between June 2017 to May 2018 (one-year study)
Type of study- The present study was a retrospective and cohort study.

Sampling method- The present study was conducted on 50 cases of breast carcinoma received during June 2017 to May 2018 (one year study) in the Department of Pathology, Karnataka Institute of Medical Sciences, as per the inclusion and exclusion criteria.

Sample size- All cases of breast carcinoma meeting the inclusion and exclusion criteria, received in the Department of Pathology, Karnataka Institute of Medical Sciences, during June 2017 to May 2018 (one year study) were included in the study.

\section{Inclusion criteria}

01. Lumpectomy specimens

02. Mastectomy specimens

\section{Exclusion criteria}

01. Trucut biopsy specimens

02. Reference slides received from outside

03. Blocks received from outside

Data collection- Patients clinical data were collected from histopathological requests and hospital records. This was a retrospective study, all the histopathological slides were retrieved and representative slides were evaluated for typing and grading of the tumour. The representative blocks were selected and sent to a standard laboratory for ER, PR, Her2neu and Ki67 in batches. Positive and negative controls were included for each batch. Correlation of ER, PR, Her2neu and Ki67 with various prognostic factors was done.

Scoring system- The Nottingham modification of the Bloom Richardson grading system (grade I, II and III) was used for histopathological grading of the breast carcinoma (Table 1).[5]

Table-1: The Nottingham modification of the Bloom Richardson grading system.

\begin{tabular}{|l|l|l|l|}
\hline \multirow{2}{*}{} & \multicolumn{3}{|c|}{ score } \\
\cline { 2 - 5 } & 1 & 2 & 3 \\
\hline Mitotic activity (per $10 \mathrm{hpf}$, field diameter $0.56 \mathrm{~mm}$ ) & $<=8$ & $9-17$ & $>=18$ \\
\hline Nuclear pleomorphism & Mild & Moderate & Marked \\
\hline Tubule formation (\%) & $>75$ & $10-75$ & $<10$ \\
\hline
\end{tabular}

Abbreviation: hpf, high power fields.

Grade I $=3$ - 5 score

Grade II = 6, 7 score 
Grade III $=8,9$ score

Interpretation of the IHC scoring was carried as given below:

Allred scoring system was used for ER and PR (a negative result was defined as a score of 0 or 2 and positive between 3-8) (Table 2)[6].

Table-2: Allred scoring system.

\begin{tabular}{|l|l|l|l|}
\hline \multicolumn{2}{|c|}{ Percentage of positive cells } & \multicolumn{2}{|c|}{ The intensity of the stain } \\
\hline 0 & No positive cells & 0 & No detectable stain \\
\hline 1 & Positive cells $<1 \%$ & 1 & Weak nuclear stain \\
\hline 2 & Positive cells $2-10 \%$ & 2 & Moderate nuclear stain \\
\hline 3 & Positive cells $11-33 \%$ & 3 & Strong nuclear stain \\
\hline 4 & Positive cells $34-66 \%$ & & \\
\hline 5 & Positive cells $>66 \%$ & & \\
\hline
\end{tabular}

Her2neu scoring of IHC slides was done as per the ASCO/CAP 2018 guidelines (American Society of Clinical Oncology and the College of American Pathologists) and cases were classified into scores of $0,1+, 2+$ and $3+$ (Table 3 )[7].

Table-3: Her2neu scoring.

\begin{tabular}{|c|c|c|}
\hline Score & Her2neu & Staining result \\
\hline 0 & Negative & $\begin{array}{l}\text { No detectable staining or membrane staining in } \\
\leq 10 \% \text { of tumour cells. }\end{array}$ \\
\hline $1+$ & Negative & $\begin{array}{l}\text { A faint partial membrane staining in }>10 \% \text { of } \\
\text { tumour cells. }\end{array}$ \\
\hline $2+$ & Equivocal & $\begin{array}{l}\text { A weak to moderate staining of the entire } \\
\text { membrane in }>10 \% \text { of tumour cells. }\end{array}$ \\
\hline $3+$ & Positive & $\begin{array}{l}\text { Strong staining of the entire membrane in }>10 \% \\
\text { of tumour cells. }\end{array}$ \\
\hline
\end{tabular}

The percentage of $\mathrm{Ki}-67$ positive cells $<15 \%$ was designated as low expression, while $\geq 15 \%$ was medium/ high expression[8].

Data analysis- The collected data were entered in Microsoft Excel worksheet and the results were compiled and analyzed statistically using SPSS-16 and were expressed as number and percentage. Chi-square test, McNemer test and Fisher exact test were used, considering ' $p$ ' value $\leq 0.05$ as a significant value.

Ethical consideration and permission: Ethical clearance was obtained from the college authorities.

\section{Results}

In the present study, the age of the patients varied from 24-72 years with the maximum number of cases belonging to $41-60$ years ( $58 \%$ of the
Patients) and the mean age of breast carcinoma (BC) patients being $49.52( \pm 11.2 S D)$ years. In this study group, 27 patients (54\%) were belonging to postmenopausal status and 23 patients (46\%) were belonging to premenopausal status. The tumour size varied from 1.5 to $12.0 \mathrm{~cm}$ in size with $94 \%$ cases with size $>2 \mathrm{~cm}$. The various histologic types were 46 cases $(92 \%)$ of Infiltrating ductal carcinomanot otherwise specified (IDC NOS), one case ( $2 \%$ ) of Medullary carcinoma and three cases (6\%) of Colloid carcinoma.

Grade II tumours were maximum, consisting of $66 \%$ (33/50) followed by Grade III tumours which were $26 \%$ (13/50) (Figure 1) and Grade I tumours accounted to $8 \%(04 / 50)$.According to the Mitotic index, $20 \%$ of the cases had Mitotic index $1,38 \%$ had Mitotic index 2 and $42 \%$ had Mitotic index 3 . Lymph nodes were recovered in 43 cases out of which metastasis was seen in 27 cases (Figure 2). Lymphovascular invasions were seen in 18 cases (36\%) and were absent in 32 cases (64\%) (Figure 3).

ER, positivity was observed in $46 \%$ of cases (23/50) and PR positivity was observed in $30 \%$ of cases $(15 / 50)$. In all of these cases, Her2neu was negative. Amongst the 50 cases, only five cases came out to be positive for Her2neu, seven cases were equivocal with $2+$ score and 38 cases were negative. The equivocal cases were not subjected to Fluorescent in situ Hybridisation and hence it was taken as negative in the present study. (Table 4, Figure 4 to 6 ).

Table-4: Percentage of ER/PR and Her2neu positive and negative cases.

\begin{tabular}{|l|l|l|l|}
\hline \multicolumn{1}{|c|}{ Status } & \multicolumn{1}{c|}{ ER } & \multicolumn{1}{c|}{ PR } & \multicolumn{1}{c|}{ Her2neu } \\
\hline Positive & $23(46 \%)$ & $15(30 \%)$ & $5(10 \%)$ \\
\hline Negative & $27(54 \%)$ & $35(70 \%)$ & $45(90 \%)$ \\
\hline Total & $50(100 \%)$ & $50(100 \%)$ & $50(100 \%)$ \\
\hline
\end{tabular}

ER and PR positivity were observed in $65.2 \%$ of cases (15/50). ER positivity alone without PR positivity was observed in $34.8 \%$ cases $(08 / 50)$ (Table 5). There were no cases of PR alone positivity with ER negativity.

Table-5: Correlation between ER and PR status.

\begin{tabular}{|l|l|l|l|}
\hline \multicolumn{1}{|c|}{ Status } & \multicolumn{1}{c|}{ ER-negative } & \multicolumn{1}{c|}{ ER-positive } & \multicolumn{1}{c|}{ Total } \\
\hline PR negative & $27(100 \%)$ & $8(34.8 \%)$ & $35(70 \%)$ \\
\hline PR positive & $0(0 \%)$ & $15(65.2 \%)$ & $15(30 \%)$ \\
\hline Total & $27(100 \%)$ & $23(100 \%)$ & $50(100 \%)$ \\
\hline
\end{tabular}


Her2neu positivity was seen in five cases and all the five cases were ER and PR negative.Triple-negative cases were 22 in number. Of the 23 ER-positive cases and 15 PR positive cases, all of these cases were Her2neu negative. Of all the ER-positive cases $(23 / 50)$ which were either PR positive (15/23) or negative cases (8/23), none of these cases was Her2neu positive in the present study (Table 6). There was a significant inverse correlation between Her2neu positivity and ER and PR negativity.

\section{Table-6: Comparison between Her2neu with ER / PR status.}

\begin{tabular}{|l|l|l|l|l|}
\hline Her2neu & ER-positive & ER-negative & PR positive & PR negative \\
\hline Positive & $0(0 \%)$ & $5(18.5 \%)$ & $0(0 \%)$ & $5(14.3 \%)$ \\
\hline Negative & $23(100 \%)$ & $22(81.5 \%)$ & $15(100 \%)$ & $30(85.7 \%)$ \\
\hline Total & $23(100 \%)$ & $27(100 \%)$ & $15(100 \%)$ & $35(100 \%)$ \\
\hline$p^{\prime}$ value & 0.001 & 0.041 & \\
\hline
\end{tabular}

The percentage of Ki67 positive cells $<15 \%$ was designated as low expression, while $\geq 15 \%$ was medium/high expression.[8] Low Ki67 proliferative index was observed in nine cases (18\%) and high in
41 cases (82\%) (Figure 7 and 8 ).

ER and PR positivity were higher in postmenopausal patients (65.2\% and $73.3 \%$ respectively). The ' $p$ ' value for both ER and PR (0.142 and 0.137 ) did not correlate with the menopausal state. Her2neu showed no correlation with the age of the patient as only five cases were positive in the study. Ki67 expression was high in premenopausal patients $(53.7 \%)$ but it was statistically insignificant $(0.051)$ (Table 7).

Six out of seven ER-negative cases were seen in tumour size of T3 category, while T2 was equally distributed with 20 out of 40 cases and $T 1$ was one out of three cases (T3>T2>T1). Similarly, six out of seven PR negative cases were in the T3 category, T2 had 27 out of 40 cases, and T1 had two out of three cases (T3>T2>T1). Her2neu showed no correlation with the size of the tumour as five cases were only positive in this study. Low Ki67 expression was seen in nine out of 31 cases in the T2 category while resting all other cases of $\mathrm{T} 1$, remaining $\mathrm{T} 2$ and all T3 category showed high Ki67 expression (Table 8).

Table-7: Age Vs ER/PR/Her2neu/Ki67.

\begin{tabular}{|l|c|c|c|c|c|l|l|l|}
\hline \multicolumn{1}{|c|}{ Age in years } & $\begin{array}{c}\text { ER } \\
\text { positive }\end{array}$ & $\begin{array}{c}\text { ER } \\
\text { Negative }\end{array}$ & $\begin{array}{c}\text { PR } \\
\text { positive }\end{array}$ & $\begin{array}{c}\text { PR } \\
\text { negative }\end{array}$ & $\begin{array}{c}\text { Her2 neu } \\
\text { positive }\end{array}$ & $\begin{array}{c}\text { Her2 neu } \\
\text { negative }\end{array}$ & $\begin{array}{c}\text { Low Ki67 } \\
\text { index }\end{array}$ & $\begin{array}{c}\text { High Ki67 } \\
\text { index }\end{array}$ \\
\hline $\begin{array}{l}\text { Premenopausal age group } \\
(<50 y r s)\end{array}$ & $8(34.8 \%)$ & $15(55.6 \%)$ & $4(26.7 \%)$ & $19(54.3 \%)$ & $3(60 \%)$ & $20(44.4 \%)$ & $1(11.1 \%)$ & $22(53.7 \%)$ \\
\hline $\begin{array}{l}\text { Postmenopausal age group } \\
(\geq 50 y r s)\end{array}$ & $15(65.2 \%)$ & $12(44.4 \%)$ & $11(73.3 \%)$ & $16(45.7 \%)$ & $2(40 \%)$ & $25(55.6 \%)$ & $8(88.9 \%)$ & $19(46.3 \%)$ \\
\hline Total & $23(100 \%)$ & $27(100 \%)$ & $15(100 \%)$ & $35(100 \%)$ & $5(100 \%)$ & $45(100 \%)$ & $9(100 \%)$ & $41(100 \%)$ \\
\hline$p^{\prime}$ value & 0.142 & 0.137 & 0.651 & & 0.051 & \\
\hline
\end{tabular}

Table-8: Tumour Size Vs ER/PR/Her2neu/Ki67.

\begin{tabular}{|l|l|l|l|l|l|l|l|l|}
\hline \multicolumn{1}{|c}{$\begin{array}{c}\text { Tumour Size } \\
\text { category }\end{array}$} & ER positive & ER negative PR positive PR negative & Her2 neu positive & Her2 neu negative/th> & Low Ki67 index & High Ki67 Index \\
\hline $\mathrm{T} 1$ & $2(8.7 \%)$ & $1(3.7 \%)$ & $1(6.7 \%)$ & $2(5.7 \%)$ & $0(0 \%)$ & $3(0 \%)$ & $0(0 \%)$ & $3(7.3 \%)$ \\
\hline $\mathrm{T} 2$ & $20(87 \%)$ & $20(74.1 \%)$ & $13(86.7 \%)$ & $27(77.1 \%)$ & $3(60 \%)$ & $37(82.2 \%)$ & $9(100 \%)$ & $31(75.6 \%)$ \\
\hline $\mathrm{T} 3$ & $1(4.3 \%)$ & $6(22.2 \%)$ & $1(6.7 \%)$ & $6(17.1 \%)$ & $2(40 \%)$ & $5(11.1 \%)$ & $0(0 \%)$ & $7(17.1 \%)$ \\
\hline Total & $23(100 \%)$ & $27(100 \%)$ & $15(100 \%)$ & $35(100 \%)$ & $5(100 \%)$ & $45(100 \%)$ & $9(100 \%)$ & $41(100 \%)$ \\
\hline $\mathrm{p}^{\prime}$ value & 0.204 & & 0.843 & & 0.258 & & 0.472 & \\
\hline
\end{tabular}

Table-9: Histological type Vs ER/PR/Her2neu/Ki67.

\begin{tabular}{|c|c|c|c|c|c|c|c|c|}
\hline Histological type & ER-positive & ER negative & PR positive & PR negative & Her2neu positive & Her2neu negative & Low Ki67 index & High Ki67 index \\
\hline IDC & $20(87 \%)$ & $26(96.3 \%)$ & $14(93.3 \%)$ & $32(91.4 \%)$ & $5(100 \%)$ & $41(91.1 \%)$ & $7(77.8 \%)$ & $39(95.1 \%)$ \\
\hline Medullary carcinoma & $0(0 \%)$ & $1(3.7 \%)$ & $0(0 \%)$ & $1(2.9 \%)$ & $0(0 \%)$ & $1(2.2 \%)$ & $0(0 \%)$ & $1(2.4 \%)$ \\
\hline Colloid carcinoma & $3(13 \%)$ & $0(0 \%)$ & $1(6.7 \%)$ & $2(5.7 \%)$ & $0(0 \%)$ & $3(6.7 \%)$ & $2(22.2 \%)$ & $1(2.4 \%)$ \\
\hline Total & $23(100 \%)$ & $27(100 \%)$ & $15(100 \%)$ & 35 (100\%) & $5(100 \%)$ & 45 (100\%) & $9(100 \%)$ & $41(100 \%)$ \\
\hline$p^{\prime}$ value & \multicolumn{2}{|l|}{0.090} & \multicolumn{2}{|l|}{1.0} & \multicolumn{2}{|l|}{1.0} & \multicolumn{2}{|l|}{0.143} \\
\hline
\end{tabular}


As IDC NOS constituted the bulk of cases (46 cases) with only one case of medullary carcinoma and three cases of colloid carcinomas there was no correlation of histological type of tumour with hormonal receptor status and Ki67 index (Table 9).

In the present study as the grade of the tumour increased the ER and PR negativity increased. This was statistically significant for ER having a ' $p$ ' value of 0.021 . However, the PR results were statistically insignificant. There was no correlation between Her2neu with tumour grade as all five Her2neu positive cases belonged to grade II. High Ki67 proliferation index significantly correlated with a higher grade of the tumour with 'p' value being 0.000 (Table 10).

\section{Table-10: Tumour Grade Vs ER/PR/Her2neu/Ki67.}

\begin{tabular}{|l|l|l|l|l|l|l|l|l|}
\hline Grade & ER positive & ER negative & PR positive & PR negative & Her2neu positive & Her2neu negative & Low Ki67 index & High Ki67 index \\
\hline Grade 1 & $4(17.4 \%)$ & $0(0 \%)$ & $3(20 \%)$ & $1(2.9 \%)$ & $0(0 \%)$ & $4(8.9 \%)$ & $4(44.4 \%)$ & $0(0 \%)$ \\
\hline Grade 2 & $16(69.6 \%)$ & $17(63 \%)$ & $10(66.7 \%)$ & $23(65.7 \%)$ & $5(100 \%)$ & $28(62.2 \%)$ & $5(55.6 \%)$ & $28(68.3 \%)$ \\
\hline Grade 3 & $3(13 \%)$ & $10(37 \%)$ & $2(13.3 \%)$ & $11(31.4 \%)$ & $0(0 \%)$ & $13(28.9 \%)$ & $0(0 \%)$ & $13(31.7 \%)$ \\
\hline Total & $23(100 \%)$ & $27(100 \%)$ & $15(100 \%)$ & $35(100 \%)$ & $5(100 \%)$ & $45(100 \%)$ & $9(100 \%)$ & $41(100 \%)$ \\
\hline$p^{\prime}$ value & 0.021 & 0.080 & 0.414 & 0.000 & \\
\hline
\end{tabular}

In the present study, there was not much of a correlation between the nodal status and ER/PR/or Her2neu receptor status. Ki67 expression was high in lymph node metastasis positive cases but statistically insignificant ('p'value - 0.984) (Table 11).

Table-11: Lymph node Vs ER/PR/Her2neu/Ki67.

\begin{tabular}{|l|l|l|l|l|l|l|l|l|}
\hline Lymph node positivity & ER-positive & ER negative & PR positive & PR Negative & Her2neu positive & Her2neu negative & Low Ki67 index & High Ki67 Index \\
\hline Negative & $8(42.1 \%)$ & $8(33.3 \%)$ & $3(25 \%)$ & $13(42 \%)$ & $2(50 \%)$ & $14(35.9 \%)$ & $3(37.5 \%)$ & $13(37 \%)$ \\
\hline Positive & $11(57.9 \%)$ & $16(66.7 \%)$ & $9(75 \%)$ & $18(58 \%)$ & $2(50 \%)$ & $25(64.1 \%)$ & $5(62.5 \%)$ & $22(63 \%)$ \\
\hline Total & $19(100 \%)$ & $24(100 \%)$ & $12(100 \%)$ & $31(100 \%)$ & $4(100 \%)$ & $39(100 \%)$ & $8(100 \%)$ & $35(100 \%)$ \\
\hline$p^{\prime}$ value & 0.554 & 0.302 & 0.209 & & 0.984 \\
\hline
\end{tabular}

While comparing lymphovascular invasion there was no significant correlation between the receptor status and Ki67 expression (Table 12).

Table-12: Lymphovascular invasion Vs ER/PR/Her2neu/Ki67.

\begin{tabular}{|l|l|l|l|l|l|l|l|l|}
\hline Vascular embolus & ER positive & ER negative & PR Positive & PR negative & Her2neu positive & Her2neu negative & Low Ki67 index & High Ki67 Index \\
\hline Absent & $18(78.3 \%)$ & $14(51.9 \%)$ & $11(73.3 \%)$ & $21(60 \%)$ & $3(60 \%)$ & $29(64.4 \%)$ & $6(66.7 \%)$ & $26(63.4 \%)$ \\
\hline Present & $5(21.7 \%)$ & $13(48.1 \%)$ & $4(26.7 \%)$ & $14(40 \%)$ & $2(40 \%)$ & $16(35.6 \%)$ & $3(33.3 \%)$ & $15(36.6 \%)$ \\
\hline Total & $23(100 \%)$ & $27(100 \%)$ & $15(100 \%)$ & $35(100 \%)$ & $5(100 \%)$ & $45(100 \%)$ & $9(100 \%)$ & $41(100 \%)$ \\
\hline$p^{\prime}$ value & 0.053 & 0.563 & 0.358 & & 1.000 & \\
\hline
\end{tabular}

In the present study ER negativity and PR negativity significantly increased with increase in mitotic Index however ' $p$ ' value was statistically insignificant for ER status (0.243). But ' $p$ ' value was significant for PR status (0.036). There was no correlation with Her2neu and mitotic Index. High Ki67 index ( $\geq 15 \%)$ has significantly correlated with high mitotic index (Table 13).

Table-13: Mitotic index Vs ER/PR/Her2neu/Ki67.

\begin{tabular}{|l|l|l|l|l|l|l|l|l|}
\hline Mitotic index & ER negative & ER positive & PR Negative & PR positive & Her2neu negative & Her2neu positive & Low Ki67 expression & High Ki67 expression \\
\hline 1 & $3(11.1 \%)$ & $6(26.1 \%)$ & $4(11.4 \%)$ & $5(33.3 \%)$ & $8(17.8 \%)$ & $1(20 \%)$ & $8(88.9 \%)$ & $1(2.4 \%)$ \\
\hline 2 & $9(33.3 \%)$ & $9(39.1 \%)$ & $11(31.4 \%)$ & $7(46.7 \%)$ & $16(35.6 \%)$ & $2(40 \%)$ & $1(11.1 \%)$ & $17(41.5 \%)$ \\
\hline 3 & $15(55.6 \%)$ & $8(34.8 \%)$ & $20(57.1 \%)$ & $3(20 \%)$ & $21(46.7 \%)$ & $2(40 \%)$ & $0(0 \%)$ & $23(56.1 \%)$ \\
\hline Total & $27(100 \%)$ & $23(100 \%)$ & $35(100 \%)$ & $15(100 \%)$ & $45(100 \%)$ & $5(100 \%)$ & $9(100 \%)$ & $41(100 \%)$ \\
\hline $\mathrm{p}^{\prime}$ value & 0.243 & 0.036 & 0.961 & & 0.00001 & \\
\hline
\end{tabular}

On comparison of Ki67 expression with ER/ PR/ Her2neu, there was no significant correlation seen as high Ki67 expression was seen in both ER/PR positive and negative cases and only five Her2neu positive cases were present in the study (Table 14). 
Table-14: Ki67 Vs ER/PR/Her2neu.

\begin{tabular}{|l|l|l|l|l|l|l|}
\hline \multicolumn{1}{|c|}{ Ki67 expression } & \multicolumn{1}{|c|}{ ER-negative } & \multicolumn{1}{c|}{ ER-positive } & \multicolumn{1}{c|}{ PR negative } & \multicolumn{1}{c|}{ PR positive } & \multicolumn{1}{c|}{ Her2neu negative } & \multicolumn{1}{c|}{ Her2neu positive } \\
\hline Low & $3(11.1 \%)$ & $6(26.1 \%)$ & $4(11.4 \%)$ & $5(33.3 \%)$ & $8(17.8 \%)$ & $1(20 \%)$ \\
\hline High & $24(88.9 \%)$ & $17(73.9 \%)$ & $31(88.6 \%)$ & $10(66.7 \%)$ & $37(82.2 \%)$ & $4(80 \%)$ \\
\hline Total & $27(100 \%)$ & $23(100 \%)$ & $35(100 \%)$ & $15(100 \%)$ & $45(100 \%)$ & $5(100 \%)$ \\
\hline $\mathrm{p}^{\prime}$ value & 0.315 & 0.148 & 0.430 & \\
\hline
\end{tabular}

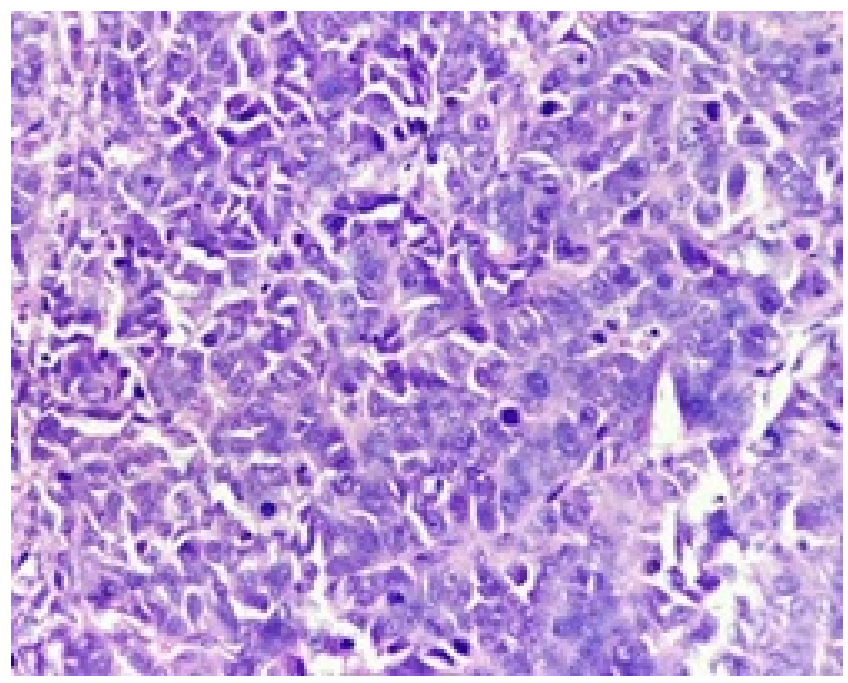

Fig-1: Grade III- Invasive ductal carcinoma (40x, $H$ and E stain).

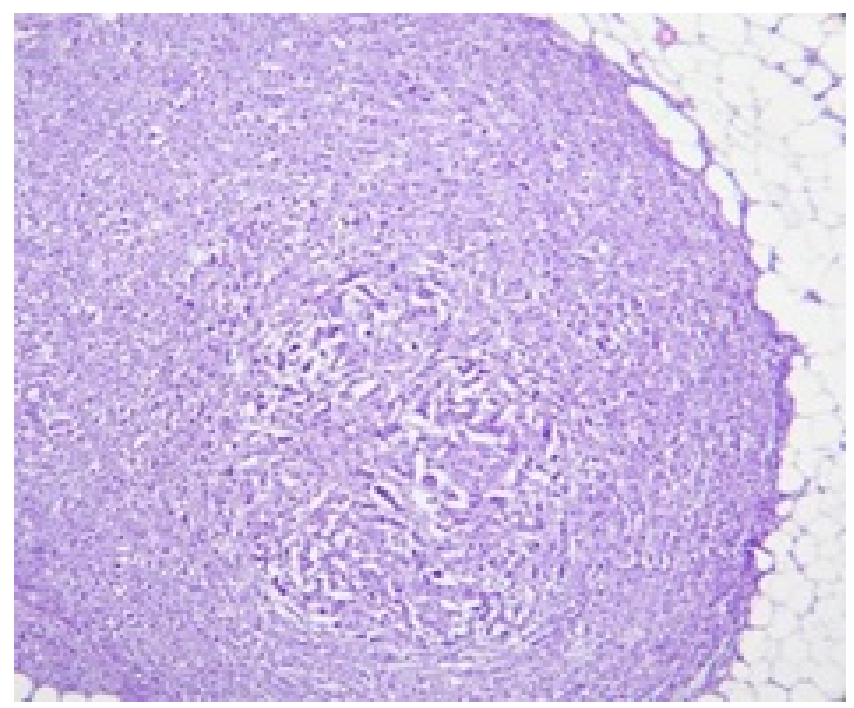

Fig-2: Lymphnode metastasis (10x, H and E stain).

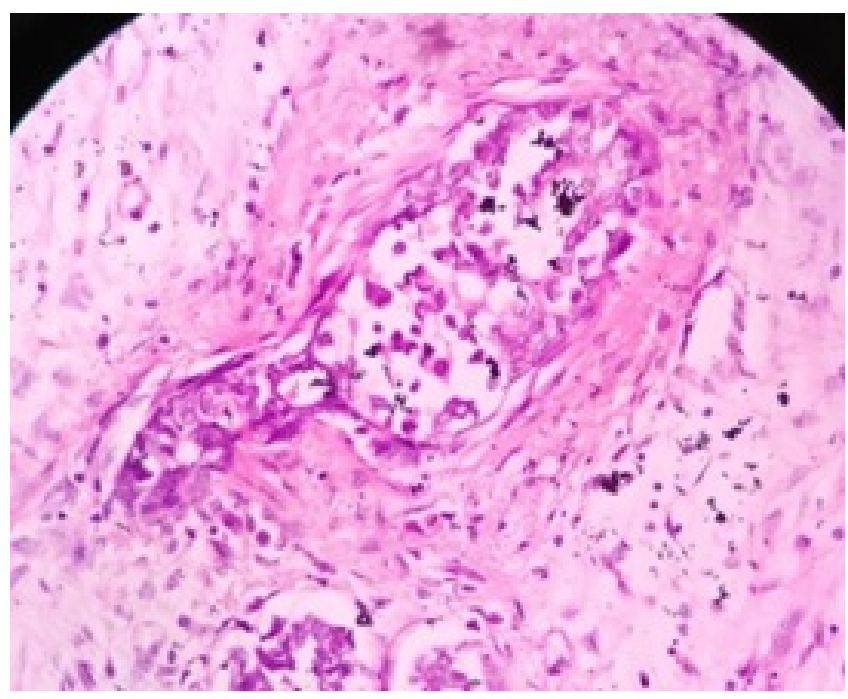

Fig-3: Lymphovascular invasion (40x, $\mathrm{H}$ and $\mathrm{E}$ stain).

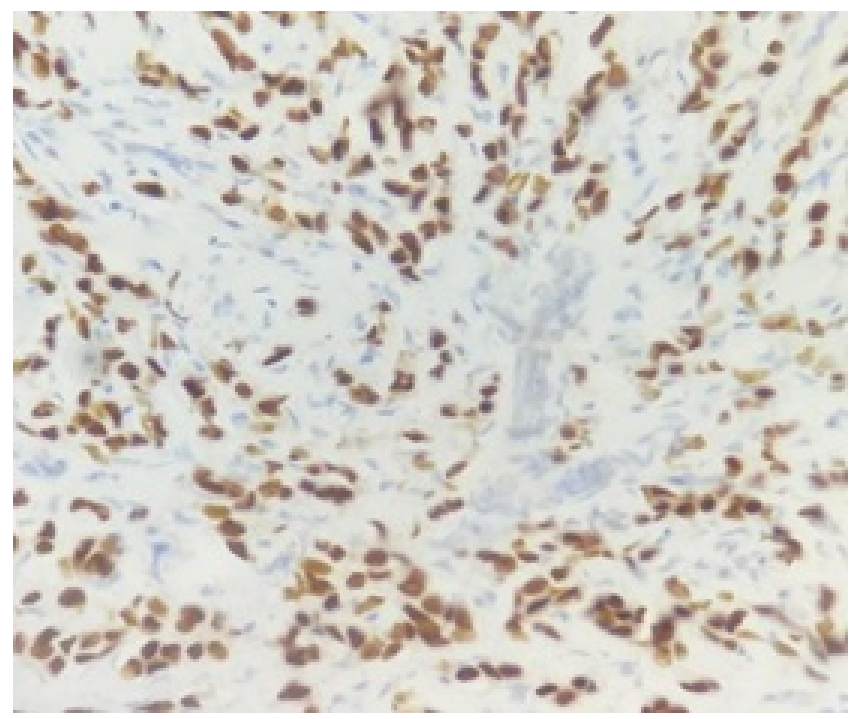

Fig-4: ER-positive- nuclear stain (40x, IHC). 


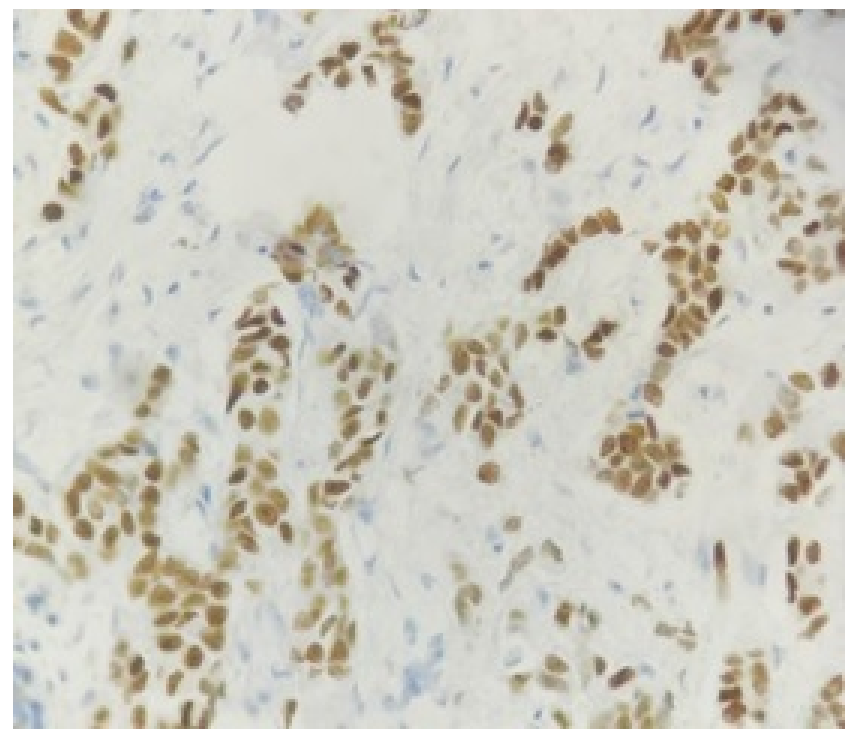

Fig-5: PR positive- nuclear stain (40x, IHC).

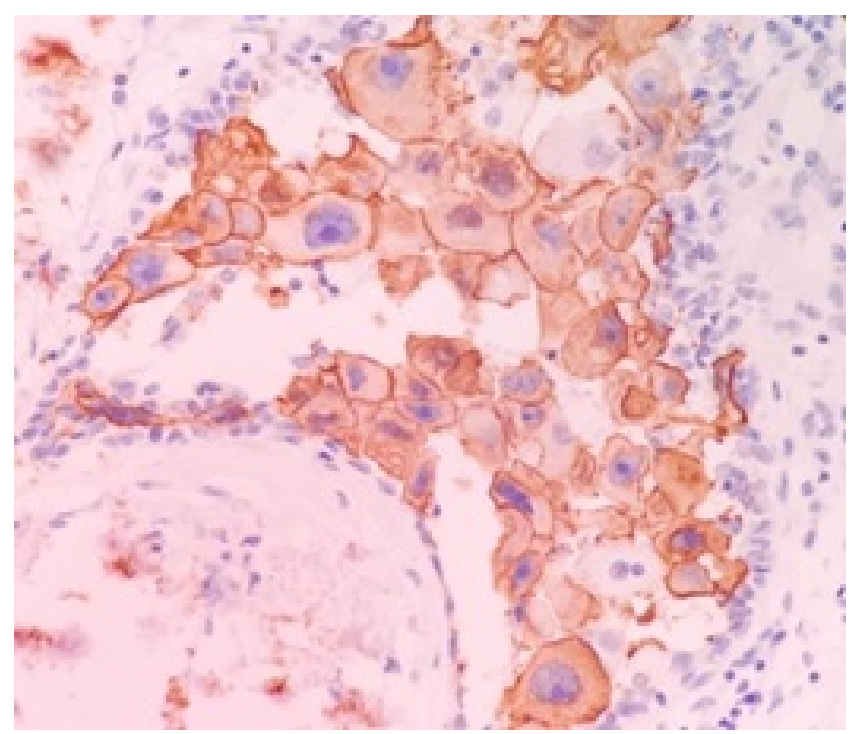

Fig-6: Her2neu- 3+ membrane positive (40x, IHC). Fig-7: Low Ki67 expression $-<15 \%$ - nuclear
stain (40x, IHC).

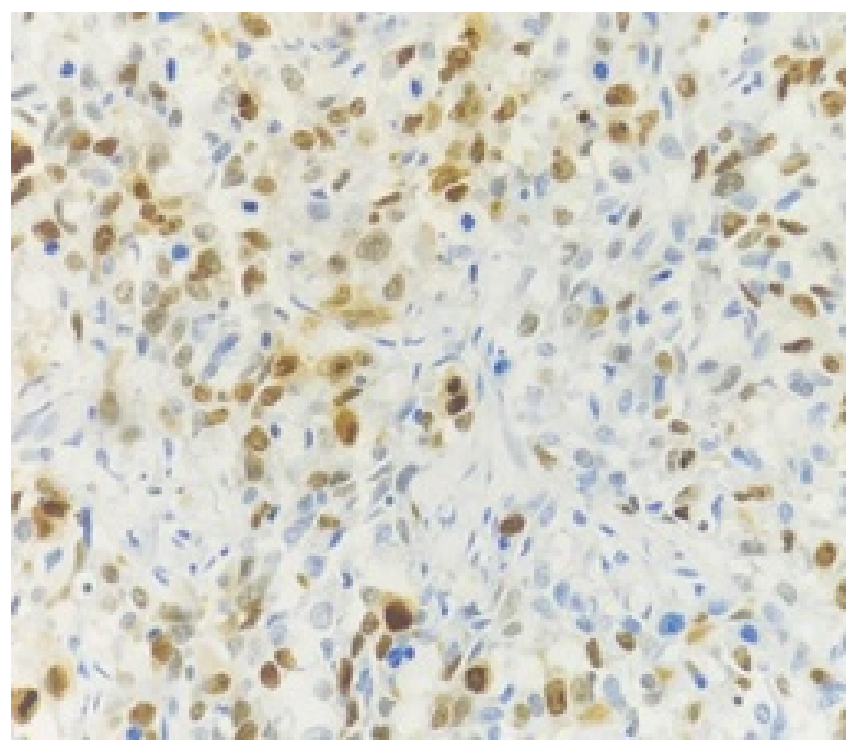

Fig-8: High Ki67 expression- $\geq 15 \%$ - nuclear stain (40x, IHC).

\section{Discussion}

Breast cancer is most common among women worldwide, its incidence is expected to increase by $26 \%$ by 2020 in developing countries[9]. Similar to the Indian and Western population studies, the mean age of $B C$ is 49.52 ( $\pm 11.2 \mathrm{SD}$ ) years and also the incidence of $B C$ is high in postmenopausal patients $(54.0 \%)$ [10].

Our present study showed estrogen receptor positivity in 23 cases comprising $46 \%$ of the total cases, which was almost similar with various Indian studies conducted by Kaur et al (36\%), Rashmi $\mathrm{K}$ et al (34.5\%)and Desai SB et al(as $32.6 \%)[9,11,12]$.

However, the incidence was higher in western authors when compared to black and Asians, which might be due to inherent biology and low incidence in Indian population may be due to decreased Hormone Replacement Therapy[13].

In the present study, $30 \%$ was positive for PR which was closely similar to Kaur et al(36\%), Rashmi $\mathrm{K}$ et al $(36.4 \%)$ and Haroon $S$ et al (38.1\%). However, Desai SB et al (46.1\%) and Ghosh J et al (51.2\%) had more number of cases of PR positivity $[9,11,12,14,15]$.

In the present study, $46 \%$ of cases showed ER positivity and $30 \%$ of cases showed PR positivity. The possible reason which can be explained could be a technical reason like antigen retrieval or prolonged cold ischemic time causing low 
Expression of PR. A statistically significant inverse relationship was obtained between Her2neu and ER expression (' $p$ ' value- 0.001) and also Her2neu and PR expression (' $p$ ' value- 0.041). A similar observation of the inverse relationship between $E R /$ PR positivity and Her2neu overexpression was seen in a study conducted by Juneja $\mathrm{S}$ et al, Almari et al, Puvitha et aland Yadav et al[16,17,18,19].

ER and PR positivity were higher which was $65 \%$ and $73 \%$ respectively in postmenopausal patients. Similar findings were noted byMohammad Faheem et al and Hussein et al[20,21].There was no correlation of Her2neu with the age of the patient in the present study, in contrast, to study done by Thiygarajan $M$ et al[10]. In premenopausal patients, Ki67 expression was high, similar to the study done by Inwald et al [22].

Hussein et al and Thiygarajan $M$ et alshowed that $69.8 \%$ and $68.2 \%$ of the patients had breast tumour size of T2 $(2-5 \mathrm{~cm})$ which is similar to the present study where $80 \%$ cases had T2 breast lesions $[10,21]$.

ER/PR, Her2neu and Ki67 expression demonstrated no significant correlation with the size of the tumour in the present study.However,Azizun-Nisa et alshowed that ER positivity decreased and Her2neu is over-expressed with increasing tumour size [23]. Similar to the present study there is no correlation of Her2neu with tumour size as per Thiygarajan M et al and Barrios GRM et al $[10,24]$.

The most common pathological type of carcinoma was IDC NOS (92\%) in the present study which was similar to the study done by Juneja $\mathrm{S}$ et al $(92.72 \%)$, Bhagat et al(94.82\%) and Thiygarajan $M$ et al $(84.3 \%)[10,16,25]$.

Receptor statuses and Ki67 expression showed no significant correlation with histological types in the present study because IDC NOS was the most predominant histological type of tumour contributing to $92 \%$ of all the types. It is similar to the study done by Thiygarajan $\mathrm{M}$ et al [10].

In the present study, it was observed ER and PR expression decreased with increasing grade of the tumour. This was statistically significant for the ER but was insignificant with PR. The possible reasons may be due to a few PR negative cases not correlating with ER-positive cases because of poor antigen retrieval or prolonged cold ischemic time for poor PR expression.

A similar observation of increasing grade of the
Tumour and ER and PR negativity was observed by Thiygarajan $M$ et al, Juneja $S$ et al, Azizun- Nisa et al, Antoniades $\mathrm{K}$ et al, Shet $\mathrm{T}$ et al and Fatima et al $[10,16,23,26,27,28]$.

Her2neu expression had no correlation with tumour grade in the current study which was similar to the studies done by Thiygarajan $\mathrm{M}$ et al,Almari et al and Barrios GRM et al $[10,17,24]$. However equivocal cases which were seven out of 50 were not confirmed by Florescent In situ Hybridisation test as our patients were unaffordable.

All these seven cases were considered as negative in this study. Hence only IHC Her2neu positive cases were considered for this study. High Ki67 proliferation index was significantly correlated with a higher grade of the tumour in the present study similar to the studies done by Haroon $S$ et al, Inwald EC et al, Peng Y, Han JS et aland Rhee $\mathrm{J}$ et al $[14,18,29,30,31]$.

ER/PR receptor status had not much of a correlation with nodal status in the current study similar to the observation in studies like Thiygarajan $M$ et al, Azizun- Nisa et al and Fatima et al $[10,23,28]$.

In the current study, there was not much of a correlation between the nodal status and Her2neu status, in contrast, to study done by Thiygarajan M et al, Azizun- Nisa et al and Naqvi et al where a significant correlation was found between Her2neu overexpression and lymph node status [10,23,32].

High Ki67 expression was seen in lymph node metastasis positive cases similar to the studies done by Peng Y, Han JS et al and Rhee J et al $[29,30,31]$.

Most number of patients presented with absent lymphovascular invasion (64\%) in the present study similar to study done by Thiygarajan $M$ et al (60\%) [10].There was no significant correlation noted between the receptor status and the Iymphovascular invasion similar to the study done by Thiygarajan $M$ et al [10].

ER negativity and PR negativity significantly increased with increase in Mitotic index similar to the study done by Thiygarajan $\mathrm{M}$ et al [10].

Her2neu and Mitotic Index had no significant correlation similar toThiygarajan $\mathrm{M}$ et al and Barrios GRM et al $[10,20]$. High Ki67 index ( $\geq 15 \%$ ) significantly correlated with the high mitotic count, which was in agreement with the results of Soliman et al, Nishimura et al and Yerushalmi et al $[33,34,35]$. 
In the present study, no correlation was found between ER, PR and Ki67 expression which was similar to the study done by Kaur et al [9]. In the present study, there was no significant association between high Ki67 positivity and positive Her2neu.

This result may be explained by the small number of Her2neu positive cases (only five), in which four cases $(91 \%)$ showed $\mathrm{Ki} 67 \geq 15 \%$. Ki67 is a proliferative marker and its expression is seen in higher-grade tumours and carries poor prognosis whereas ER/PR expression is associated with lower grade tumour and has a better prognosis.

So all breast cancer patients should be subjected to all 4 markers (ER, PR, Her2neu and Ki67) where $E R, P R, H e r 2 n e u$ expression defines the line of treatment and $\mathrm{Ki} 67$ expression defines the prognosis especially high Ki67 expression in ER, PR negative cases carries a poor prognosis. Breast cancer with high Ki67 expression responds better to chemotherapy $[36,37]$.

\section{Limitations of the present study}

Equivocal cases of Her2neu were not confirmed by FISH due to financial constraints of the patient which has an effect of Her2neu true positivity.

\section{Conclusion}

- The present study concludes that ER, PR reveals inverse relationship and $\mathrm{Ki} 67$ showed a direct relationship with the grade of the tumour.

- Increased Ki67 proliferative index was associated with increased mitotic activity and less expression of ER, PR; thus carrying a poor prognosis and requires treatment accordingly.

\section{What does the study add to the existing knowledge?}

This study shows that the addition of Ki67, a proliferative marker is an important predictive and prognostic marker. Future work should focus on specifications of its role in treatment decisions.

\section{Author's contributions}

Dr.Purushotham Reddy: Conceptualized the study, senior author on the manuscript, helped with manuscript construction, data analysis and proofreading.
Dr.Mithraa Devi S: Helped with data collection, analysis, manuscript construction and involved in the submission of the final report.

\section{Reference}

01. WHO Globocan 2018 World. Factsheets CancersBreast Factsheet. IARC; WHO. [Internet] [2019].

Available From:

[Article:http://gco.iarc.fr/today/data/factsheets/canc ers/20-Breast-fact-sheet.pdf][Crossref]

02. WHO Globocan 2018 India. Factsheets Populations- India Factsheet. IARC; WHO. [Internet] [2019].

AvailableFrom:

[Article:http://gco.iarc.fr/today/data/factsheets/popul ations/356-india-fact-sheets.pdf][Crossref]

03. Moutafoff C, Coutant C, Bezu C. Prognostic and predictive factors in multifocal breast carcinoma. Gynecol Obstet Fertil. 2011;39(7-8)425-432. doi:

[Article:https://doi.org/10.1016/j.gyobfe.2011.05.00 1][Crossref]

04. Baulies S, Cusido M, Gonzalez-Cao M. Hormone receptor and HER2 status- the only predictive factors of response to neoadjuvant chemotherapy in breast cancer. J Obstet Gynaecol. 2015;35(5)485-489.

doi:

[Article:https://doi.org/10.3109/01443615.2014.968 113][Crossref]

05. Tuffaha MSE, Guski H, Kristiansen G, editors Immunohistochemistry in Tumor Diagnostics. Springer International Publishing AG. Chapter 10, Markers and Immunoprofile of Breast Tumors. 2018; p71-81.

doi: [Article:https://doi.org/10.1007/978-3-31953577-7_10][Crossref]

06. Wolff AC, Hammond ME, Allison KH, Harvey BE, Mangu PB, Bartlett JM et al. Human Epidermal Growth Factor Receptor 2 Testing in Breast Cancer- American Society of Clinical Oncology/College of American Pathologists Clinical Practice Guideline Focused Update. J Clin Oncol. 2018 Jul 10;36(20)2105-2122.

doi:

[Article:https://doi.org/10.1200/JCO.2018.77.8738]

[Crossref] 
07. Elston CW, Ellis IO. Pathological prognostic factors in breast cancer-I The value of histological grade in breast cancer- experience from a large study with long-term follow-up. Histopathology. 1991;19(5)403-410.

doi: [Article:https://doi.org/10.1111/j.13652559.1991.tb00229.x][Crossref]

08. Engstrom MJ, Opdahl S, Hagen AI, Romundstad $P R$, Akslen LA, Haugen $O A$, et al. Molecular subtypes, histopathological grade and survival in a historic cohort of breast cancer patients. Breast Cancer Res Treat. 2013;140(3)463-473. doi: [Article:https://doi.org/10.1007/s10549-0132647-2][Crossref]

09. Thiygarajan M, Navrathan N, Mohanapriya T, Kumar A, Singh B. Correlation between estrogen receptor, progesterone receptor, HER-2/neu status and other prognostic factors in carcinoma breast in Indian population. Int Surg $\mathrm{J}$. 2015;2(4)515-22.

doi: [Article:http://dx.doi.org/10.18203/23492902.isj20151000][Crossref]

10. Kaur K, Kaur H, Gill HS, Kaur M. Evaluation of expression and correlation of ER, PR and $\mathrm{Ki} 67$ tumour markers in breast carcinoma. Int $\mathrm{J}$ Contemp Med Res. 2016;3(10)3047-3051.

[Crossref]

11. Ghosh J, Gupta S, Desai S, Shet T, Radhakrishnan S, Suryavanshi $P$, et al. Estrogen, progesterone and HER2 receptor expression in breast tumours of patients, and their usage of HER2-targeted therapy, in a tertiary care centre in India. Indian J Cancer. 2011;48(4)391-396.

doi: [Article:https://doi.org/10.4103/0019509X.92245][Crossref]

12. Desai SB, Moonim MT, Gill AK, Punia RS, Naresh KN, Chinoy RF. Hormone receptor status of breast cancer in India- a study of 798 tumours. Breast. 2000;9(5)267-270.

doi: [Article:https://doi.org/10.1054/brst.2000.0134] [Crossref]

13. Tewari M, Pradhan S, Singh U, Shukla HS. Estrogen and progesterone receptor status in breast cancer- effect of oral contraceptive pills and hormone replacement therapy. Breast. 2007; 16(5)540-545.

doi:

[Article:https://doi.org/10.1016/j.breast.2007.05.005 ][Crossref]
14. Rashmi K, Sharma J, Minhas SS, Mardi K. Hormone Receptor Status of Breast Cancer in the Himalayan Region of Northern India. Indian J Surg. 2011;73(1)9-12.

doi: [Article:https://doi.org/10.1007/s12262-0100121-5][Crossref]

15. Haroon $S$, Hashmi AA, Khurshid $A$, Kanpurwala MA, Mujtuba S, Malik B, Faridi N. Ki67 index in breast cancer- correlation with other prognostic markers and potential in pakistani patients. Asian Pac J Cancer Prev. 2013;14(7)4353-4358. doi:

[Article:https://doi.org/10.7314/apjcp.2013.14.7.435 3][Crossref]

16. Juneja $S$, Agarwal R, Agarwal D, Rana P, Singh $\mathrm{K}$, Kaur S. Correlation of expression of estrogen receptor, progesterone receptor and human epidermal growth factor receptor-2 with histopathological grade in cases of carcinoma breast. Int J Contemp Med Res. 2019;6(9)I6I11.

doi:

[Article:http://dx.doi.org/10.21276/ijcmr.2019.6.9.26 ][Crossref]

17. Faheem M, Mahmood H, Khurram M, Qasim U, Irfan J. Estrogen receptor, progesterone receptor, and Her2 neu positivity and its association with tumour characteristics and menopausal status in a breast cancer cohort from northern Pakistan. E cancer medical science. 2012;6;283.

doi:

[Article:https://doi.org/10.3332/ecancer.2012.283]

[Crossref]

18. Inwald EC, Schalke MK, Hofsta"dter F, Zeman F, Koller M, Gerstenhauer $M$ et al. Ki67 is a prognostic parameter in breast cancer patientsresults of a large population-based cohort of a cancer registry. Breast Cancer Res Treat. 2013;139;539-552.

doi: [Article:https://doi.org/10.1007/s10549-0132560-8][Crossref]

19. Hussein MR, Abdul Wahed SR, Abdul Wahed AR. Alterations of estrogen receptors, progesterone receptors and c-erbB2 oncogene protein expression in ductal carcinomas of the breast. Cell Bio lint. 2008;32(6)698-707.

doi:

[Article:https://doi.org/10.1016/j.cellbi.2008.01.007] [Crossref] 
15. Almari MN, Hamad M. Immunohistochemical evaluation of human epidermal growth factor receptor 2 and estrogen and progesterone receptors in breast carcinoma in Jordan. Breast Cancer Res. 2005;7(5)598-604.

doi: [Article:https://doi.org/10.1186/bcr1200] [Crossref]

16. Yadav R, Sen R, Chauhan P. ER, PR, HER-2/neu status and relation to clinicopathological factors in breast carcinoma. Int J Pharm Pharm Sci. 2016;8(4):287-290.

Available from:[Article:https://innovareacademics.

in/journals/index.php/ijpps/article/view/10776]

[Crossref]

17. Puvitha RD, Shifa S. Breast Carcinoma, Receptor Status and Her-2/neu Expression Revisited. Int J Sci Stud. 2016;3(10)52-58.

doi: [Article:https://doi.org/10.17354/ijss/2016/11] [Crossref]

18. Barrios GRM. HER2/neu incidence in early breast cancer and its correlation with others prognostic factors. J Clin Oncol. 2008;26(15)22195-22195. doi:

[Article:https://doi.org/10.1200/jco.2008.26.15_supp I.22195][Crossref]

19. AzizunN, Bhurgri Y, Raza F, Kayani N. Asian Comparison of ER, PR and Her2neu (C-erb B 2) reactivity pattern with histologic grade, tumour size and lymph node status in breast cancer. Pac J Can Prev. 2008;9(4)553-556.

[Crossref]

20. Bhagat VM, Jha BM, Patel PR. Correlation of Hormonal Receptor and Her-2/neu Expression in Breast Cancer- A Study at Tertiary Care Hospital in South Gujarat. Natl J Med Res. 2012;2(3)295-298.

[Crossref]

21. Antoniades K, Spector H. Correlation of Estrogen Receptor levels with Histology and Cytomorphology in Human Mammary Cancer. Am J Clin Path. 1979;71(5)497-503.

doi: [Article:https://doi.org/10.1093/ajcp/71.5.497] [Crossref]

22. Shet T, Agrawal A, Nadkarni M, Palkar M, Havaldar R, Parmar V, et al. Hormone receptors over the last 8 years in a cancer referral centre in India- What was and what is?. Ind J Pathol Microbiol. 2009;52(2)171-174.

doi: [Article:https://doi.org/10.4103/03774929.48909][Crossref]
19. Rhee J, Han SW, Oh DY, Kim JH, Im SA. The clinicopathologic characteristics and prognostic significance of triple-negativity in node-negative breast cancer. BMC Cancer. 2008;8;307-309.

doi: [Article:https://doi.org/10.1186/1471-2407-8307][Crossref]

20. Fatima S, Faridi N, Gill S. Breast cancer- steroid receptors and other prognostic indicators. J Coll Physicians Surg Pak. 2005;15(4)230-233. [Crossref]

21. Peng Y. Potential prognostic tumour biomarkers in triple-negative breast carcinoma. Beijing $\mathrm{Da}$ XueXue Bao Yi Xue Ban. 2012;44(5)666-672. [Crossref]

22. Han JS, Cao D, Molberg KH, Sarode VR, Rao R. Hormone receptor status rather than HER2 status is significantly associated with increased Ki67 and p53 expression in triple-negative breast carcinomas, and high expression of Ki67 but not p53 is significantly associated with axillary nodal metastasis in triple- negative and high-grade non-triple-negative breast carcinomas. Am J Clin Pathol. 2011;135(2)230237.

doi:[Article:https://doi.org/10.1309/ajcp9dv3evzu atfv][Crossref]

23. Naqvi SQH, Jamal Q, Mahmood RK, Zaidi SMH, Abbas F. Significance of Her2 neu oncoprotein over expression on node positive invasive breast cancer. J Coll Physicians Surg Pak. 2002;12;534-537.

[Crossref]

24. Soliman NA, Yussif SM. Ki 67 as a prognostic marker according to breast cancer molecular subtype. Cancer Biol Med. 2016;13(4)496-504.

doi: [Article:https://doi.org/10.20892/j.issn.20953941.2016.0066][Crossref]

25. Nishimura R, Osako T, Okumura Y, Hayashi M, Toyozumi $Y$, Arima N. Ki67 as a prognostic marker according to breast cancer subtype and a predictor of recurrence time in primary breast cancer. Exp Ther Med. 2010;1(5)747-754.

doi: [Article:https://doi.org/10.3892/etm.2010.133] [Crossref]

26. Yerushalmi R, Woods R, Ravdin PM, Hayes MM, Gelmon KA. Ki67 in breast cancer- prognostic and predictive potential. Lancet Oncol. 2010;11(2)174-183.

doi: [Article:https://doi.org/10.1016/S14702045(09)70262-1][Crossref] 
24. Jones RL, Salter J, Hern RA, Nerurkar A, Parton $M$, Reis-Filho JS, et al. Relationship between oestrogen receptor status and proliferation in predicting response and long-term outcome to neoadjuvant chemotherapy for breast cancer. Breast Cancer Res Treat. 2010;119(2)315-323. doi: [Article:https://doi.org/10.1007/s10549-0090329-x][Crossref]
29. Brown RW, Allred CD, Clark GM, Osborne CK, Hilsenbeck SG. Prognostic value of $\mathrm{Ki67}$ compared to S-phase fraction in axillary nodenegative breast cancer. Clin Cancer Res. $1996 ; 2(3) 585-592$.

[Crossref] 